\title{
THE STUDENTS' DISCIPLINE AND SOCIAL BEHAVIOR OF MA MIFTAHUL ULUM CERMENAN NGORO JOMBANG CORRELATION
}

\author{
Khudriyah \\ Prodi PAI STIT al Urwatul WutsqoJombang \\ e-mail: azkiabilqis@gmail.com \\ Azifatun Najahah \\ Prodi PAI STIT al UrwatulWutsqoJombang \\ e-mail: najahahazifatun@yahoo.com
}

\begin{abstract}
:
In the process of teaching and learning, disciplinary habits can foster students' social behavior. For students who have high discipline will behave well socially wherever they are. Researchers are interested in examining the relationship of students' discipline with social behavior of MA MiftahulUlumCermenan Ngoro Jombang. This research method is quantitative research. The results of the product moment analysis found that there was a very significant positive correlation between discipline and students' social behavior. It is known that the results of the discipline of students belonging to the low category which are 4 respondents or $7.27 \%$, middle category there are 19 respondents or $34.55 \%$, and classified as high category there are 32 respondents or $58.18 \%$. While the results of the social behavior of MA students. Miftahul 'UlumCermenan Ngoro Jombang which is in the low category there is one respondent or $1.81 \%$, which is classified as middle category there are 21 respondents or $38.19 \%$, and classified as high category there are 33 respondents or $60.00 \%$. The conclusion of this study shows that there is a significant and strong relationship between discipline and social behavior of MA MiftahulUlumCermenan Ngoro Jombang students, because the hypothesis test results show that the $r$ count of 0.841 is greater than the $r$ table of 0.2656 , and the significance value is $0.000<0.05$.
\end{abstract}

Keywords: Discipline, Social Behavior, Students

\section{A. Background of Study}

Discipline is very important to be applied wherever someone is, because with the application of discipline, humans can carry out their activities without obstacles. Some of the obstacles that occur are due to the lack of human discipline in terms of time, energy, and economics, social as well as morals. As Hurlock explains, discipline is very important in moral development ${ }^{1}$. Through child

\footnotetext{
${ }^{1}$ Hurlock, E. B. Psikologi Perkembangan: Suatu Pendekatan Sepanjang Rentang Kehidupan, (Jakarta: Erlangga, 2006), 163.
} 
discipline and students learn to behave in accordance with their social group, children and students learn to behave that are acceptable and unacceptable.

According to Thomas Gordon (1996: 3), Discipline is behavior andorder in accordance with the rules and regulations, or behavior obtained from training that is carried out continuously ${ }^{2}$. Every human being is required to have discipline in any circumstances in everyday life, since it cannot be separated from life activities. Improving the quality of human resources is one of the stresses of educational goals ${ }^{3}$. As stated in Law no. 20 of 2003 about objectives of National Education Chapter II Article 3 such as:

"National Education aims to develop capabilities and shape the character and civilization of a nation with dignity in order to educate the nation, aiming at developing the potential of students to become human beings who believe and fear God Almighty, have noble character, are healthy, knowledgeable, capable, creative, independent and become democratic and responsible citizens"

Those activities will cause a habit. The habit of carrying out activities regularly and on time is what is usually called discipline in everyday life. Discipline is needed anywhere, because with discipline an orderly and orderly life will be created.

According to Abdullah NasihUlwan, the discipline problem is an important factor in determining the good and bad behavior of students, so that discipline needs to be cultivated in the school environment and in everyday life. If the students have discipline, then good behavior will grow in these students, for example: being honest, trustworthy, and also having a noble character ${ }^{5}$.In practicing however, it is very difficult; as information has been heard either in newspaper or many other information sources shows that implementation of discipline is hard word to be done. One the other hand some schools have good students social behavior.

Good social behavior of students can be realized because of the support from various parties, both family environment, school environment, and community environment. In addition to developing good social behavior from an

\footnotetext{
${ }^{2}$ Gordon, B.Davis, KerangkaDasarSistemInformasiManajemen, PPM, Jakarta, 2002.

${ }^{3}$ Hasbullah. Dasar dasar ilmu Pendidikan. (Jakarta: PT Raja Grafindo Persada, 2006),307.

${ }^{4}$ UndangUndangNo. 20 Tahun 2003 tentangtujuanPendidikanNasional

5 Abdullah NashihUlwan, PendidikanAnakdalam Islam, PustakaAmani, Jakarta, 2002.
} 
early age, good social behavior also needs to be trained because good social behavior does not appear by itself. Good social behavior needs to be trained and accustomed to, attitude behavior and life patterns and discipline are not formed in a short time, but through a process that takes a long time.

According to HadariNawawi, discipline is an effort to continuously build awareness in working or studying properly in the sense that everyone is actively carrying out their functions or a situation where people who are members of an organization are subject to existing regulations with a sense of happy ${ }^{6}$.

Classroom discipline is defined as an orderly condition in which teachers and students obey class rules, so that they can carry out their respective duties and functions effectively in implementing the learning process in the classroom. Thus discipline includes aspects of an orderly, obedient, diligent, and tenacious atmosphere. Learning discipline is very necessary, therefore, for it gives birth to the spirit of appreciating time, not wasting time passing in a vacuum. For people who are successful in learning and working because of their capabilityto place discipline above for all their life activities. Based on the above statement, it can be concluded that discipline is something that affects the success of students by obeying the rules of law, or obedience in the use of time to learn effectively and efficiently.

Sudrajat explained that school discipline is a school effort to maintain student behavior so as not to deviate and can encourage students to behave in accordance with the norms, rules and regulations that apply at school $^{7}$. Furthermore, Arikunto explained that discipline refers to one's obedience in following the rules and regulations because it is driven by something from outside, for example because they want to get praise from their superiors. Furthermore, the definition of discipline or strategy refers to one's obedience in following the rules because it is driven by the awareness that is in the conscience ${ }^{8}$.

\footnotetext{
${ }^{6}$ Nawawi, Manajemen Sumber Daya Manusia: Untuk Bisnis Yang Kompetitif, Gajah mada University Press, Yogyakarta, 2011.

${ }^{7}$ Akhmad Sudrajat, Pengertian Pendekatan, Strategi, Metode, Teknikdan Model Pembelajaran. Bandung :Sinar Baru Algensindo, 2008.

${ }^{8}$ SuharsimiArikunto.Manajemen Pengajaran Secara Manusiawi (Jakarta: PT. RinekaCipta, 1990), 22.
} 
Exemplary is a personal image that is well displayed by someone to be imitated or idolized, while the authority of the impression of physical and nonphysical appearance that causes students to respect, respect teachers and parents as educators touches the personal lives of students. Thus it can be understood that student discipline can be pursued by providing examples of teacher exemplary and authority, so that students feel ashamed if they behave undisciplined.

Discipline can not only be formed in school, discipline is also formed through a process of a series of behaviors that show the values of obedience to God, order, and order in gaining knowledge ${ }^{9}$. According toArikunto, learning discipline is a person's obedience in following the rules or regulations driven by the awareness of his conscience ${ }^{10}$. This attitude will grow through training, education, coaching, and modeling so that it becomes a habit. Cultivating an attitude of discipline must start from childhood until the development of the individual concerned, both in the family, school and community environment. Cultivatingit from early will result strong discipline.

Such activities will influence the discipline, as self-awareness, practice, habits, and also punishment. For students, learning discipline will also not be created if students do not have self-awareness. Students will be disciplined in learning if students are aware of the importance of learning in life. Discipline cultivation needs to be started as early as possible from within the family environment. Starting from the habit of getting up in the morning, eating, sleeping, and bathing must be done in a timely manner so that the child will get used to doing these activities continuously.

The following are discipline function which students need to know that by having higher discipline they can achieveoptimal learning outcomes. They are: Arranging life together. Humans are social creatures. Humans will not be able to live without other people's rocks. In social life, there are often conflicts between people because of a conflict of interest, because humans are not only social beings but also as individual beings who cannot be separated from their ego, so that sometimes in society there are conflicts between personal interests and common interests. This is where the importance of discipline to integrate the order of

\footnotetext{
${ }^{9}$ Abdul Rochim, SosiologiPendidikan, (Surakarta: UNS Press, 2009),48.

${ }^{10}$ Ibid, 114.
} 
human life in certain groups or in society. So that social life will be peaceful and orderly.

The second is Build personality. Personality is a whole trait, typical behavior possessed by a person. Between one person and another person has a different personality. A well-disciplined environment is very influential on one's personality.Moreover, a student who is growing in personality, of course, an orderly school environment that calm, and serene plays a very important role in building a good personality. The third is training a good personality. Apart from being built from an early age, a good personality needs to be trained because it does not appear itself. A good personality needs to be trained and accustomed to, behavior attitudes and patterns of life and discipline are not formed in a short time, but through a process that takes a long time.

The next is Coercion. Discipline will be created with one's awareness to comply with all applicable rules, regulations and numbers in carrying out duties and responsibilities. Discipline with self-awareness motives is better and stronger. Doing obedience and obedience to self-awareness is beneficial for one's own goodness and progress. Conversely, discipline can also occur because of coercion and pressure from outside. For example, when a student who is less disciplined enters a well-disciplined school, he is forced to obey and obey the rules of the school.

Punishment of school is rules or regulations. This code of conduct contains positive things and must be done by students. The other side contains sanctions or penalties for those who violate these rules. Punishment plays a very important role because it can provide motivation and strength for students to comply with the existing rules and regulations, because without punishment it is very doubtful that students will obey the predetermined rules. Educational sanctions are sanctions that consciously set the goal of changing a person's behavior and actions with processes and forms that contain educational value.

The last is creating conducive environment. School discipline functions to support the implementation of educational activity process running smoothly. This is achieved by designing school regulations, namely regulations for teachers and for students, as well as other regulations deemed necessary. Then implemented 
consistently and consequently, it is hoped that the school will become an educational environment that is safe, calm, serene, and orderly.

According to Arikunto in his research on discipline, he divided three kinds of disciplinary indicators, namely: 1) disciplinary behavior in the classroom, 2) disciplinary behavior outside the classroom in the school environment, and 3) disciplinary behavior at home ${ }^{11}$.

In line with Arikunto, Syafrudin dividing learning discipline indicators into four types, namely: 1) obedience to study time, lesson assignments, use of learning facilities, and obedience to maintaining time to come and go ${ }^{12}$. Therefore, the researcher in this study dividing the learning discipline indicators into four types, namely: Adherence to school rules, obedience to learning activities at school, in doing lesson assignments and obedience to learning activities at home. Discipline has correlation with social behavior.

Social behavior is a person's ability to become a social person shown by individuals in social life as a response to what is accepted or vice versa by the community group ${ }^{13}$. Those behavior shown by their feelings, actions, attitudes, beliefs, or respect for others. Behavior is often said as moral or action appropriate or expected by others that come from their own heart without any force.

Behavior can be divided into natural behavior (Innate Behavior) and operant behavior. Natural behavior is behavior that is brought from birth, in the form of reflex and instincts, while operant behavior is behavior that is formed through the learning process. Operant behavior is a behavior that is formed, learned and can be controlled, bybecause it can change through the learning process ${ }^{14}$.Therefore, every individual has a behavior that we can observe regularlysense of sight or not, and behavior can change through processes learn during the individual interacts with others in his life.

\footnotetext{
${ }^{11}$ Ibid, 137.

${ }^{12}$ Ibid, 80.

${ }^{13}$ Hurlock, Elizabeth B. (2003). Psikologi Perkembangan :Suatu Pendekatan SepanjangvRentang Kehidupan. Jakarta : Erlangga, 261

${ }^{14}$ Anggraini, Fr. Reni Retno, 2006, "Pengungkapan Informasi Sosial dan Faktor Faktor yang Mempengaruhi Pengungkapan Informasi Sosial Dalam Laporan Keuangan Tahunan (Studi Empiris pada Perusahaan-perusahaan yang Terdaftar di Bursa Efek Jakarta)', Simposium Nasional Akuntansi.
} 
Behavior is an individual's response or reaction to support the environment ${ }^{15}$. It is an activity of the organism in question, seen from biological perspective. However, behavior is an act, behavior, habit and behavior based on Poerwodarminto over view ${ }^{16}$.Social behavior is an attitude, action or behavior in which there is mutual interaction with fellow humans who need and support one another. In this study, it is limited to the readiness and willingness of children or students in social relations which is characterized by following teaching and learning activities until completion, being helpful in terms of kindness, mutual respect, and a life of tolerance.Thus, what is meant by social behavior is a condition that exists within a person (student) that encourages him to behave in relation to the rules, regulations or norms that exist in school.

The structure of behavior can be divided into 4 (four) types, including: 1) Hierarchical behavior, constitute as behavior that shows that it is wrong one behavior can only be done if the other behavior can control it. 2) Procedural behavior is behavior that shows the position of one series of behavior performance sequences, but none of which is a prerequisite behavior for the other. 3) Grouping behavior can be said as a special behavior that is independent of one another, even though everything is related in such a situation, a connecting line between one particular behavior and another is not needed. 4) Combined behavior, it is general behavior which, when broken down into specific behaviors, the bulk of the structure is a combination of hierarchical, procedural and grouping structures ${ }^{17}$.

He then explained that the social interactions are caused some factors as imitation, suggestion, identification and sympathy factors. And social interaction is the relationship between one individual and another. One individual can influence another individual or vice versa. So there is a reciprocal relationship ${ }^{18}$.

Social attitudes can be formed from within as well as external influencing factors. This external influence can be done from the explanation of the subject in school and the attitude of the teacher when interacting with students. Likewise

\footnotetext{
${ }^{15}$ DepartemenPendidikandanKebudayaan, KamusBesarBahasa Indonesia, Jakarta: Balai Pustaka,1994), 25.

${ }^{16}$ Poerwadarminta, W.J.S. KamusUmumBahasa Indonesia. Jakarta: Balai Pustaka.1995

${ }^{17}$ BimoWalgito, PsikologiSosiologi, (Yogyakarta: Andi Offset, 1980), 106

${ }^{18}$ Ibid, 155.
} 
what happened at MA MiftahulUlumCermenan Ngoro which is proved that most of teachers and students have a pretty good social attitude.

Discipline and social behavior have correlation, since discipline can shape the social behavior of students. Discipline is cultivated, developed, and applied as well as a result of interactions with the environment, especially the social environment.According to Arikunto, discipline is a person's obedience in following the rules or regulations because it is driven by the awareness that is in his conscience. Discipline is closely related to self-control of a person or students in taking action consciously through the formation of a person's self and character or social behavior ${ }^{19}$. The personality needs to be built from an early age, it also needs to be trained and they can grow through a disciplined process.

Based on the explanation above, the authors conclude that discipline is needed in an effort to improve an orderly life and improve the social behavior of students because of its regulatory and educational nature. Most successful people have high discipline that is embedded in their every activity.

\section{B. Method}

This research is ex-post facto, namely the type of research that is the independent variable is an event that has already occurred. According to Sugiyono, ex-post facto is a research conducted to research events that have occurred and then trace them to back to find out the factors that can cause the incident $^{20}$. This means that this study aims to determine the factors affect student discipline and social behavior. This research approach is a quantitative approach, namely research where the data obtained relates to the numbersled to the use of statistical analysis techniques. The research design used in is associative design. According to Sugiyono, associative design is useful for analyze the relationship between one variable and other variables or how one variable affects another variable $\mathrm{e}^{21}$.

The sample was all students of MA MiftahulUlumCermenan Ngoro Jombangthat was 55 students. The researcher used questionnaires as technique to collect data and, and then the data was analyzed using product moment as

\footnotetext{
${ }^{19}$ Ibid, 114.

${ }^{20}$ Sugiyono, MetodePenelitian PendidikanPendekatanKuantitatif, kualitatif, dan R\&D. Bandung: Alfabeta, 2010.

${ }^{21}$ Ibid, 14.
} 
formula. Test the validity and reliability of the instrument was carried out by internal testing conducted by experts who mastery the field, in this case about discipline and social behavior. From 40 statements of discipline tested all is valid, and from 45 statements of social behavior tested to be 40 valid, and used as instrument of research.

\section{Result}

The research result is discussing about three concerning three things, namely discipline, social attitudes and the relationship both students' discipline and social behavior.

Based on the tabulation of scores about the relationship between students' discipline and social behavior of MAMiftahulUlumCermenan Ngoro Jombang, can be seen at the following tables:

Table 1

Data of students discipline of Miftahul 'UlumCermenan Ngoro Jombang

\begin{tabular}{|c|c|c|c|c|c|}
\hline No & Subject & Total & No & Subject & Total \\
\hline 1. & 1 & 151 & 31. & 31 & 152 \\
\hline 2. & 2 & 151 & 32. & 32 & 151 \\
\hline 3. & 3 & 151 & 33. & 33 & 153 \\
\hline 4. & 4 & 148 & 34. & 34 & 152 \\
\hline 5. & 5 & 150 & 35. & 35 & 151 \\
\hline 6. & 6 & 152 & 36. & 36 & 150 \\
\hline 7. & 7 & 150 & 37. & 37 & 148 \\
\hline 8. & 8 & 151 & 38. & 38 & 151 \\
\hline 9. & 9 & 152 & 39. & 39 & 154 \\
\hline 10. & 10 & 152 & 40. & 40 & 146 \\
\hline 11. & 11 & 150 & 41. & 41 & 152 \\
\hline 12. & 12 & 152 & 42. & 42 & 149 \\
\hline 13. & 13 & 153 & 43. & 43 & 148 \\
\hline 14. & 14 & 152 & 44. & 44 & 149 \\
\hline 15. & 15 & 151 & 45. & 45 & 152 \\
\hline 16. & 16 & 150 & 46. & 46 & 151 \\
\hline 17. & 17 & 148 & 47. & 47 & 149 \\
\hline 18. & 18 & 146 & 48. & 48 & 152 \\
\hline 19. & 19 & 150 & 49. & 49 & 151 \\
\hline 20. & 20 & 151 & 50. & 50 & 146 \\
\hline & & & & & \\
\hline
\end{tabular}




\begin{tabular}{|c|c|c|c|c|c|}
\hline 21. & 21 & 152 & 51. & 51 & 151 \\
\hline 22. & 22 & 150 & 52. & 52 & 150 \\
\hline 23. & 23 & 151 & 53. & 53 & 149 \\
\hline 24. & 24 & 149 & 54. & 54 & 153 \\
\hline 25. & 25 & 152 & 55. & 55 & 146 \\
\hline 26. & 26 & 152 & & & \\
\hline 27. & 27 & 148 & & & \\
\hline 28. & 28 & 152 & & & \\
\hline 29. & 29 & 148 & & & \\
\hline 30. & 30 & 151 & & & \\
\hline
\end{tabular}

Based on the data presented in the above table, $\mathrm{t}$ can be seen that the frequency and percentage of the students discipline. The highest score achieved is 154 and the lowest is 146 , then it is used to determine the classification of discipline frequency and percentage as the following table.

Table 2

Students'discipline percentage of MA Miftahul 'UlumCermenan Ngoro Jombang

\begin{tabular}{|c|c|c|c|c|}
\hline No & Category & Interval & Frequency & Percentage \\
\hline 1 & Low & $145-147$ & 4 & $7,27 \%$ \\
\hline 2 & Middle & $148-150$ & 19 & $34,55 \%$ \\
\hline 3 & High & $151-153$ & 32 & $58,18 \%$ \\
\hline \multicolumn{3}{|c|}{ Total } & 55 & $100 \%$ \\
\hline
\end{tabular}

The data is also can be seen at the following chat pie:

Chat 1. Students discipline percentage of MA Miftahul 'UlumCermenan Ngoro Jombang 


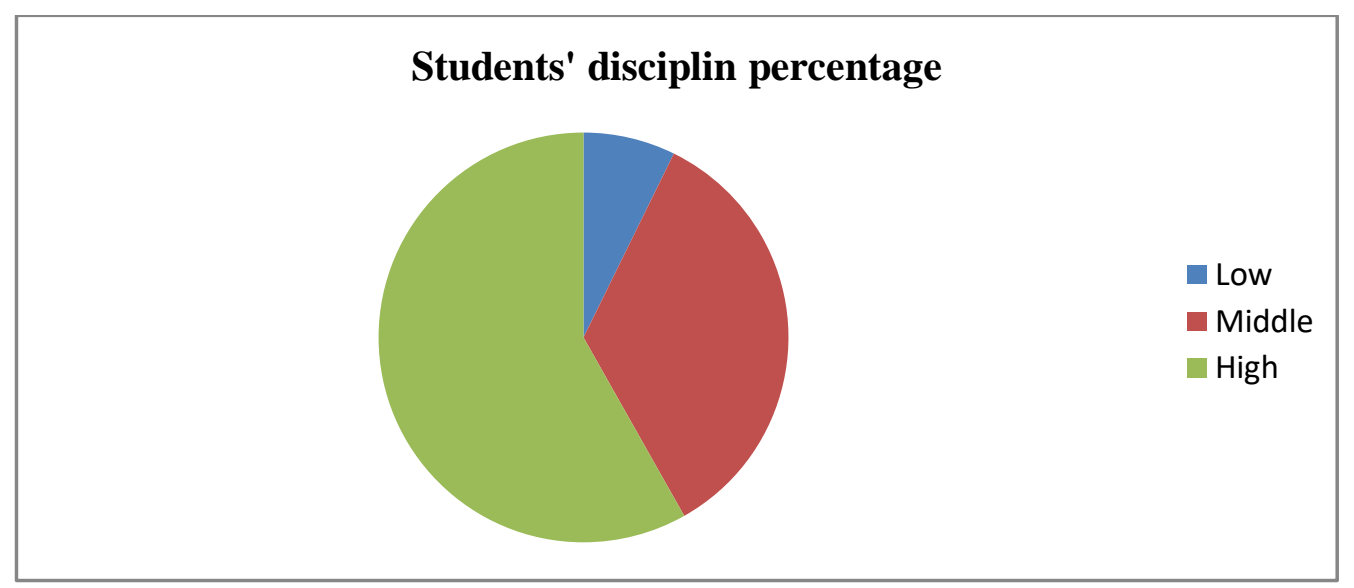

The data shows that from 55 students, there are $4(7,27 \%)$ students get low category, $19(34,55 \%)$ have middle category, and $32(58,18 \%)$ students have high category of discipline. Based on the data found, it can be concluded that the students of MA Miftahul 'UlumCermenan Ngoro Jombangmostly have high discipline.

Table 3

Data of student'ssocial behaviorof MAMiftahul 'UlumCermenan Ngoro Jombang

\begin{tabular}{|c|c|c|c|c|c|}
\hline No & Subject & Total & No & Subject & Total \\
\hline 1. & 1 & 147 & 31. & 31 & 152 \\
\hline 2. & 2 & 151 & 32. & 32 & 148 \\
\hline 3. & 3 & 148 & 33. & 33 & 148 \\
\hline 4. & 4 & 149 & 34. & 34 & 151 \\
\hline 5. & 5 & 151 & 35. & 35 & 152 \\
\hline 6. & 6 & 152 & 36. & 36 & 153 \\
\hline 7. & 7 & 152 & 37. & 37 & 149 \\
\hline 8. & 8 & 147 & 38. & 38 & 151 \\
\hline 9. & 9 & 143 & 39. & 39 & 151 \\
\hline 10. & 10 & 148 & 40. & 40 & 148 \\
\hline 11. & 11 & 149 & 41. & 41 & 153 \\
\hline 12. & 12 & 151 & 42. & 42 & 153 \\
\hline 13. & 13 & 151 & 43. & 43 & 150 \\
\hline 14. & 14 & 151 & 44. & 44 & 151 \\
\hline 15. & 15 & 151 & 45. & 45 & 151 \\
\hline 16. & 16 & 151 & 46. & 46 & 152 \\
\hline 17. & 17 & 151 & 47. & 47 & 150 \\
\hline 18. & 18 & 147 & 48. & 48 & 152 \\
\hline 19. & 19 & 151 & 49. & 49 & 151 \\
\hline
\end{tabular}




\begin{tabular}{|l|l|l|l|l|l|}
\hline 20. & 20 & 152 & 50. & 50 & 151 \\
\hline 21. & 21 & 151 & 51. & 51 & 155 \\
\hline 22. & 22 & 148 & 52. & 52 & 150 \\
\hline 23. & 23 & 148 & 53. & 53 & 147 \\
\hline 24. & 24 & 149 & 54. & 54 & 152 \\
\hline 25. & 25 & 151 & 55. & 55 & 151 \\
\hline 26. & 26 & 148 & & & \\
\cline { 1 - 3 } 27. & 27 & 148 & & & \\
\cline { 1 - 2 } 28. & 28 & 149 & & & \\
\cline { 1 - 2 } 29. & 29 & 153 & & & \\
\cline { 1 - 2 } 30. & 30 & 152 & & & \\
\cline { 1 - 3 } & & & & &
\end{tabular}

The above data shows thatthe frequency and percentage of the students social behavior from 55 students, the highest score achieved is 155 and the lowest is 143 , and then the classification of student's social behavior frequency and percentage as the following table.

Table 4

Students'social behavior percentage of MA Miftahul 'UlumCermenan Ngoro Jombang

\begin{tabular}{|c|c|c|c|c|}
\hline No & Category & Interval & Frequency & Percentage \\
\hline 1 & Low & $141-145$ & 1 & $1,81 \%$ \\
\hline 2 & Middle & $146-150$ & 21 & $38,19 \%$ \\
\hline 3 & High & $151-155$ & 33 & $60,00 \%$ \\
\hline \multicolumn{3}{|c|}{ Total } & 55 & $100 \%$ \\
\hline
\end{tabular}

The chat pie about students' social behavior as follow:

Chat 2. Students'social behavior percentage of MA Miftahul 'UlumCermenan Ngoro Jombang 


\section{Students' social behavior percentage}

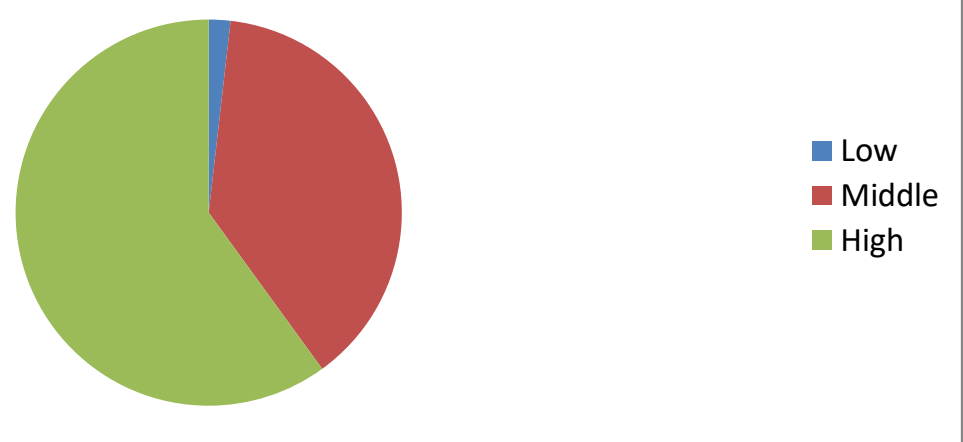

The data about students social behavior shows that from 55 students, there are $1(1,81 \%)$ students get low category, $21(38,19 \%)$ have middle category, and $33(60 \%)$ students have high category. Based on the data above, it can be concluded that mostly the students of MA Miftahul 'UlumCermenan Ngoro Jombang have high social behavior.

To know whether or not the students' discipline and social behavior at MA Miftahul 'UlumCermenan Ngoro Jombang have correlation, hypothesis test is conducted. And to determine the correlation level is based on the following interpretation. From the both data, it can be seen that both of them have correlation.

Table 5.Correlation interpretation of the correlation

\begin{tabular}{|c|c|}
\hline r value & Interpretation \\
\hline $0,800-1,000$ & Very strong \\
\hline $0,600-0,799$ & Strong \\
\hline $0,400-0,599$ & Middle \\
\hline $0,200-0,399$ & low \\
\hline $0,000-0,199$ & Very low (no correlation) \\
\hline
\end{tabular}

The result of hypothesis test is as follows:

Table 6 . the result of hypothesis test

\begin{tabular}{|c|c|c|c|r|r|}
\hline No & $\mathrm{X}$ & $\mathrm{Y}$ & $\mathrm{X}^{2}$ & $\mathrm{Y}^{2}$ & \multicolumn{1}{|c|}{$\mathrm{XY}$} \\
\hline 1 & 151 & 147 & 22801 & 21609 & 22197 \\
\hline
\end{tabular}




\begin{tabular}{|c|c|c|c|c|c|}
\hline 2 & 151 & 151 & 22801 & 22801 & 22801 \\
\hline 3 & 151 & 148 & 22801 & 21904 & 22348 \\
\hline 4 & 148 & 149 & 21904 & 22201 & 22052 \\
\hline 5 & 150 & 151 & 22500 & 22801 & 22650 \\
\hline 6 & 152 & 152 & 23104 & 23104 & 23104 \\
\hline 7 & 150 & 152 & 22500 & 23104 & 22800 \\
\hline 8 & 151 & 147 & 22801 & 21609 & 22197 \\
\hline 9 & 152 & 143 & 23104 & 20449 & 21736 \\
\hline 10 & 152 & 148 & 23104 & 21904 & 22496 \\
\hline 11 & 150 & 149 & 22500 & 22201 & 22350 \\
\hline 12 & 152 & 151 & 23104 & 22801 & 22952 \\
\hline 13 & 153 & 151 & 23409 & 22801 & 23103 \\
\hline 14 & 152 & 151 & 23104 & 22801 & 22952 \\
\hline 15 & 151 & 151 & 22801 & 22801 & 22801 \\
\hline 16 & 150 & 151 & 22500 & 22801 & 22650 \\
\hline 17 & 148 & 151 & 21904 & 22801 & 22348 \\
\hline 18 & 146 & 147 & 21316 & 21609 & 21462 \\
\hline 19 & 150 & 151 & 22500 & 22801 & 22650 \\
\hline 20 & 151 & 152 & 22801 & 23104 & 22952 \\
\hline 21 & 152 & 151 & 23104 & 22801 & 22952 \\
\hline 22 & 150 & 148 & 22500 & 21904 & 22200 \\
\hline 23 & 151 & 148 & 22801 & 21904 & 22348 \\
\hline 24 & 149 & 149 & 22201 & 22201 & 22201 \\
\hline 25 & 152 & 151 & 23104 & 22801 & 22952 \\
\hline 26 & 152 & 148 & 23104 & 21904 & 22496 \\
\hline 27 & 148 & 148 & 21904 & 21904 & 21904 \\
\hline 28 & 152 & 149 & 23104 & 22201 & 22648 \\
\hline 29 & 148 & 153 & 21904 & 23409 & 22644 \\
\hline 30 & 151 & 152 & 22801 & 23104 & 22952 \\
\hline 31 & 152 & 152 & 23104 & 23104 & 23104 \\
\hline 32 & 151 & 148 & 22801 & 21904 & 22348 \\
\hline 33 & 153 & 148 & 23409 & 21904 & 22644 \\
\hline 34 & 152 & 151 & 23104 & 22801 & 22952 \\
\hline 35 & 151 & 152 & 22801 & 23104 & 22952 \\
\hline 36 & 150 & 153 & 22500 & 23409 & 22950 \\
\hline 37 & 148 & 149 & 21904 & 22201 & 22052 \\
\hline 38 & 151 & 151 & 22801 & 22801 & 22801 \\
\hline 39 & 154 & 151 & 23716 & 22801 & 23254 \\
\hline 40 & 146 & 148 & 21316 & 21904 & 21608 \\
\hline 41 & 152 & 153 & 23104 & 23409 & 23256 \\
\hline 42 & 149 & 153 & 22201 & 23409 & 22797 \\
\hline
\end{tabular}




\begin{tabular}{|r|r|r|r|r|r|}
\hline 43 & 148 & 150 & 21904 & 22500 & 22200 \\
\hline 44 & 149 & 151 & 22201 & 22801 & 22499 \\
\hline 45 & 152 & 151 & 23104 & 22801 & 22952 \\
\hline 46 & 151 & 152 & 22801 & 23104 & 22952 \\
\hline 47 & 149 & 150 & 22201 & 22500 & 22350 \\
\hline 48 & 152 & 152 & 23104 & 23104 & 23104 \\
\hline 49 & 151 & 151 & 22801 & 22801 & 22801 \\
\hline 50 & 146 & 151 & 21316 & 22801 & 22046 \\
\hline 51 & 151 & 155 & 22801 & 24025 & 23405 \\
\hline 52 & 150 & 150 & 22500 & 22500 & 22500 \\
\hline 53 & 149 & 147 & 22201 & 21609 & 21903 \\
\hline 54 & 153 & 152 & 23409 & 23104 & 23256 \\
\hline 55 & 146 & 151 & 21316 & 22801 & 22046 \\
\hline Total & $\sum X$ & $\sum Y$ & $\sum x 2$ & $\sum Y 2$ & $\sum X Y$ \\
& 8272 & 8262 & 1244306 & 1241342 & 1242630 \\
\hline
\end{tabular}

Based on the result of correlation test using SPSS 17, 00 can be seen as follows:

Tabel 7

Result of correlation test between students' discipline and social behavior of MA

Miftahul 'UlumCermenan Ngoro Jombang

Correlations

\begin{tabular}{|ll|r|r|}
\hline & & Discipline & Social behavior \\
\hline Discipline & Pearson Correlation & 1 & $.841^{* *}$ \\
& Sig. (2-tailed) & & .000 \\
& $\mathrm{~N}$ & 55 & 55 \\
\hline Social & Pearson Correlation & $.841^{* *}$ & 1 \\
behavior & Sig. (2-tailed) & .000 & \\
& $\mathrm{~N}$ & 55 & 55 \\
\hline
\end{tabular}

The correlation analysis of the output results of SPSS version 17.0 shows the value of the correlation coefficient between students discipline and social behavior is 0.841 . The value of $r$ tablewith the degrees of freedom of $(55-2)=53$ and a significant level of $5 \%$, is 0.2656 . This means that $r$ count is higher than $r$ 
table. And based on the testing criteria, Ha accepted and Ho rejected if $r$ count> from $r$ table.Ho is accepted and $\mathrm{Ha}$ is rejected if $\mathrm{r}$ count $<$ from $r$ table. Related to the result of analysis $r$ count $>$ from $r$ table. It means that there is a relationship between students discipline and social behavior of MA Miftahul 'UlumCermenan Ngoro Jombang.Or the increasing student discipline will be accompanied by increased social behavior.

Meanwhile, to prove whether or not the correlation between students discipline and social behavior is significant, can be seen the p-value in the sig (2tailed) column $0.000<0.05$ means that students discipline and the social behavior of MA Miftahul 'UlumCermenan Ngoro Jombang has a significant relationship.

Based on the asterisk (**) from the output above, it is known that the Pearson correlation value of each variable connected has a two-star sign. It means that there is a correlation between the variables being correlated that is students' discipline and students' social behavior.

\section{Conclusion}

The students' discipline of MA MiftahulUlumCermenan Ngoro Jombang can be said high, because from 55 students who researchedthere are 7, $27 \%$ or 4 students have low category, $34,55 \%$ or 19 have middle category, and $58,18 \%$ or 32 students have high category of discipline.The students' social behavior of MA MiftahulUlumCermenan Ngoro Jombang can be said high, since from all respondents or 55 students mostly have high social behavior that is only one respondent $(1.81 \%)$ has low social behavior, 21 respondents $(38.19 \%)$ have middle category, and $33(60 \%)$ students have high category of social behavior. There is a strong and significant relationship between students' discipline and social behavior of MA MiftahulUlumCermenan Ngoro Jombang. It is indicated by a significance value of $0.000<0.05$ and the counted $r$ value with significant degree of $5 \%$ is greater than the $r$ table or $(0.841>0.2656)$. 


\section{BIBLIOGRAPHY}

Abdul Rochim, SosiologiPendidikan, Surakarta: UNS Press, 2009.

Abdullah NashihUlwan, Pendidikan Anak dalam Islam, Pustaka Amani, Jakarta, 2002.

Akhmad Sudrajat. Pengertian Pendekatan, Strategi, Metode, Teknik dan Model Pembelajaran. Bandung :SinarBaruAlgensindo, 2008.

Anggraini, Fr. Reni Retno. Pengungkapan Informasi Sosial dan Faktor Faktor yang Mempengaruhi Pengungkapan Informasi Sosial Dalam Laporan Keuangan Tahunan (Studi Empiris pada Perusahaan-perusahaan yang Terdaftar di Bursa Efek Jakarta), SimposiumNasionalAkuntansi. 2006.

BimoWalgito, PsikologiSosiologi, Yogyakarta: Andi Offset, 1980.

Departemen Pendidikan dan Kebudayaan, KamusBesarBahasa Indonesia, Jakarta: Balai Pustaka,1994.

Gordon, B.Davis, Kerangka Dasar Sistem Informasi Manajemen, PPM, Jakarta, 2002.

Hasbullah. Dasar dasar ilmu Pendidikan. Jakarta: PT Raja Grafindo Persada, 2006.

Hurlock, Elizabeth B. Psikologi Perkembangan :Suatu Pendekatan Sepanjang Rentang Kehidupan. Jakarta : Erlangga, 2003.

Nawawi, Manajemen Sumber Daya Manusia: Untuk Bisnis Yang Kompetitif, Gajah mada University Press, Yogyakarta, 2011.

Poerwadarminta, W.J.S..Kamus Umum Bahasa Indonesia. Jakarta: Balai Pustaka.1995.

SuharsimiArikunto.Manajemen Pengajaran Secara Manusiawi (Jakarta: PT. Rineka Cipta,1990.

UndangUndangNo. 20 tentang tujuan Pendidikan Nasional, 2003. 